\title{
Performance evaluation of high capacity mechanised dehusking equipment for green arecanut (Areca catechu L.)
}

\author{
Ravindra Naik, R.H. Sadvatha, T. Senthilkumar and V. Balaji \\ ICAR-Central Institute of Agricultural Engineering, Regional Centre, Coimbatore-641 007, Tamil Nadu, India
}

(Manuscript Received: 18-03-2020, Revised: 06-07-2020, Accepted: 10-07-2020)

\begin{abstract}
India is a major arecanut (Areca catech $u$ L.) growing country. Of the many problems identified in arecanut processing, dehusking is found to be a major one, which is cumbersome and needs to be mechanised. Presently, there are a few types of equipments available, but these machines are basically of low capacity and cater to small arecanut growers. Performance evaluation of three high capacity green arecanut dehusking equipments was taken up, to work out its possible adoption for entrepreneurship development. Equipment under evaluation consisted of power mounted dehusker with hook tooth cutting blade fixed in a cutting wheel to dehusk the outer shell with a nut ejection system coupled with a vibrating deck of trays to grade and convey the dehusked nuts. The Blade-Knurl shaft speed ratio was optimised as 1:11. Whole nut recovery per cent ranged from $81.84 \pm 1.87$ to $82.52 \pm 1.95$ per cent. The unhusked per cent and partially husked percentage ranged from $7.60 \pm 3.71$ to $7.81 \pm 4.68$ and $8.29 \pm 2.15$ to $8.85 \pm 2.82$, respectively. The broken nut percentage ranged from $1.03 \pm 1.36$ to $2.06 \pm 2.72$ percentage. The total cost of operation for two-belt, four-belt and six-belt model was ₹ $162 \mathrm{~h}^{-1}$, ₹ $237 \mathrm{~h}^{-1}$ and $₹ 262 \mathrm{~h}^{-1}$, respectively. Better dehusking efficiency with reduced damage to the nuts achieved in mechanical dehusking would enable the farmer to realise additional yield with saving in time and lower cost of operation.
\end{abstract}

Keywords: Arecanut, dehusking, efficiency, operating capacity, power consumption

\section{Introduction}

Arecanut (Areca catechu) is an important commercial crop in India. Its production in India is dominant in the coastal region within 400 kilometres from the coastline, and also in some other noncoastal states of India. It is popularly known as betel nut, as its common usage in the country is for mastication with betel leaves (Vion et al., 2017). 'Areca' is taken up from the Malayan language, which means 'cluster of nuts'. It has commercial and economic importance not only in India but also in China and South-East Asia. Within India, Karnataka produces 67.22 per cent of the crop, followed by Kerala and Assam (www.dasd.gov.in, 2020). There are two varieties of arecanut viz., White Supari and Red Supari (Anand et al., 2012). White Supari is prepared by harvesting fully ripened arecanut followed by sun-drying for 40 to 50 days. After drying the nut, shell of the nut has to be removed by hand/machine. Red Supari is prepared by harvesting the tender (green) arecanut, peeling off the husk and boiling it (Vion et al., 2017). White variety accounts for 60 per cent of the product with the rest going for red. During the crop cycle, adopting modern input technologies, including mechanisation, is required to improve productivity (Ramappa and Manjunatha, 2013). Among many problems, identified, dehusking has been identified as a tedious and time-consuming process which needs to be mechanised (Pradeep and Raghvendra, 2012; Asokan et al., 2014).

Dehusking is the most important activity in the entire arecanut processing (Baboo, 1981; Balasubramanian and Panwar, 1986; Aviara et al., 2012). The raw fruit has to be peeled to get its kernel, and this has to be done within 24-36 hours after harvesting (Aviara et al., 2012; Asokan et al., 2014; Suhas et al., 2016). Otherwise, cutting will not be

*Corresponding Author: naikravindra@gmail.com 
easy, and quality will start deteriorating. Manual dehusking of arecanut is a slow process and needs skilled labour. Due to the lack of skilled labour, fresh areca nuts cannot be dehusked immediately. Some efforts have been made to develop a dehusking unit for dry arecanut (Varghese and Jacob 1998; Jarimopas and Niamhom, 2004; Niamhom et al., 2007; Jarimopas et al.,2009; Aware et al., 2016; Suhas et al.,2016; Bellubbi et al., 2018). The machines are not suitable to dehusk fresh green/tender arecanuts, which needs a different mechanism for peeling (Vijayakumar et al., 2017; Nalawade et al., 2018). Most of the reported equipment for dehusking of green arecanut is manually operated or of very low capacity of few kilograms per hour which is not acceptable for commercial production (Kiran et al., 2014; Asokan et al., 2014; Joy et al., 2015; Alfaz et al., 2018). The machines of low capacity will not be suitable for large scale dehusking process, custom hiring and entrepreneurship development. For commercial adoption of equipment, it should be of higher capacity and also need to have good dehusking efficiency with lower broken nuts. The machine should be simple in design, easy to operate by unskilled person and portable. The present investigation was taken up to study the dehusking efficiency of high capacity tender (green) arecanut dehusking equipment and its suitability for adoption for entrepreneurship development based on its capacity, performance and cost economics.

\section{Materials and methods}

\section{Preparation of arecanut for dehusking}

Fresh green arecanuts of Thirthahalli variety were selected for the present investigation. The arecanuts were harvested 7-8 months after flowering. The harvested nuts were collected free of external, unwanted materials and transported to arecanut processing yard. The basic concept of a dehusking machine of the tender arecanut is depicted in Figure 1. The important components are cutting wheel, blade, tub and knurl shaft. Dehusking is done by shearing action between cutting wheel and the knurl shaft. To get the best output in terms of the higher dehusking and a lower amount of unhusked, partially husked and broken nuts, the ratio between the speed of cutting wheel and the knurl shaft need to be optimised. A preliminary experiment was carried out to optimise the speed ratio between cutting wheel and knurl shaft, which could be adopted for high capacity green arecanut dehusker.

\section{Optimising the speed of dehusking equipment}

Optimisation of speed of operation of arecanut dehusking was carried out based on the speed ratio between the knurl shaft and wheel/blade shaft. The

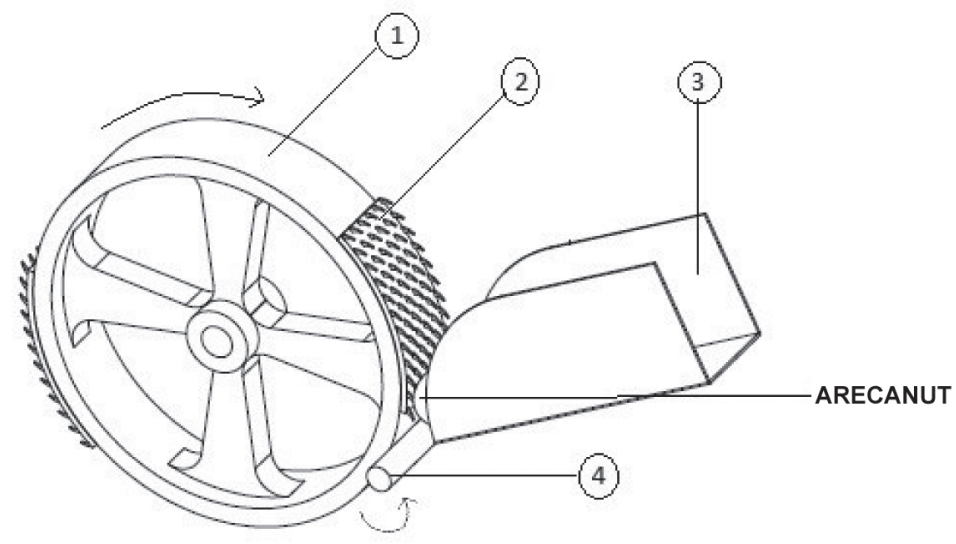
1. Cutting wheel
2. Blade
3. Tub
4. Knurl shaft

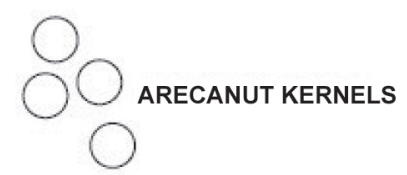

Fig. 1. Concept of green arecanut dehusking 


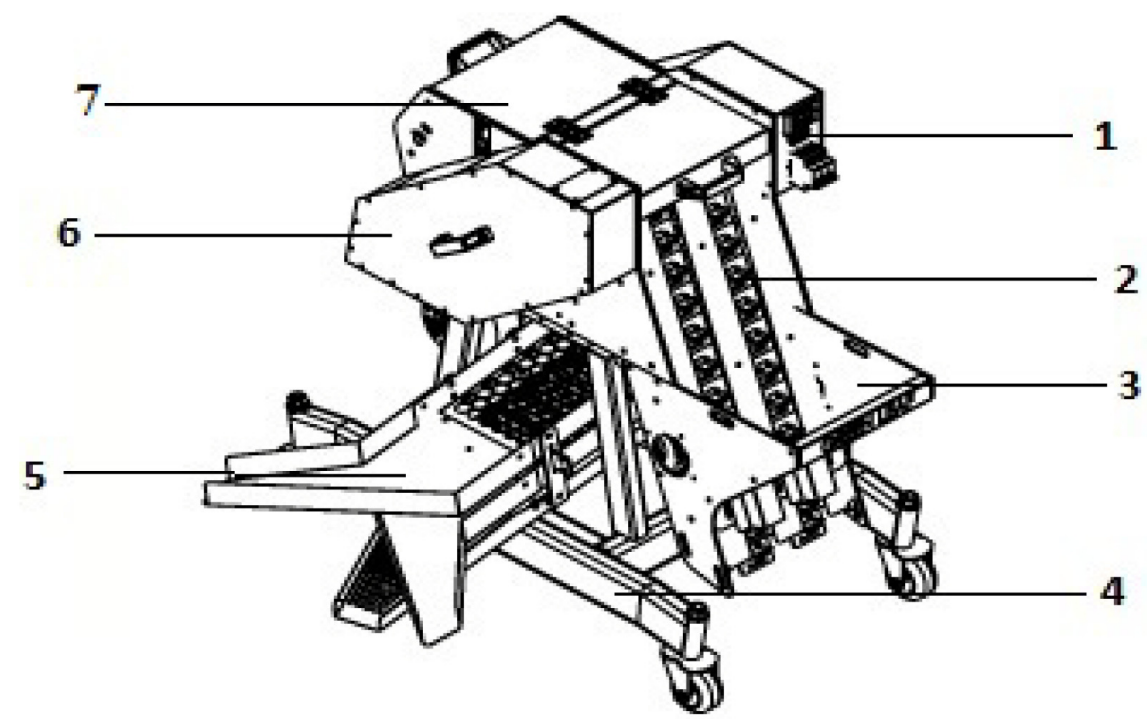

1. Power source; 2. Feeding conveyors; 3. Feed hopper; 4. Outer frame;

5. Discharge outlets; 6. Transmission cover; 7.Top safety cover

Fig. 2. Isometric view of arecanut dehusker

data was recorded in terms of feed inlet and output viz., whole nuts, unhusked nuts, partially dehusked nuts and broken nuts. A set up was made to vary the speed ratio between the blade shaft and knurl shaft in the range of 1:10 to 1:12 (Vishwanathan, 2014; Patent No: 259204). The optimum ratio was fixed based on various parameters like whole nut recovery, unhusked, partially dehusked and broken nuts. Based on the optimum ratio, performance evaluation of three models of arecanut dehusking equipment was carried out at the optimised speed of operation. Each trial was replicated five times.

\section{Functional parts of arecanut dehusking machine}

The arecanut dehusking machine consists of a power source, feeding conveyor, feeding hopper, outer frame, discharge outlets, transmission cover and top safety cover (Fig. 2).

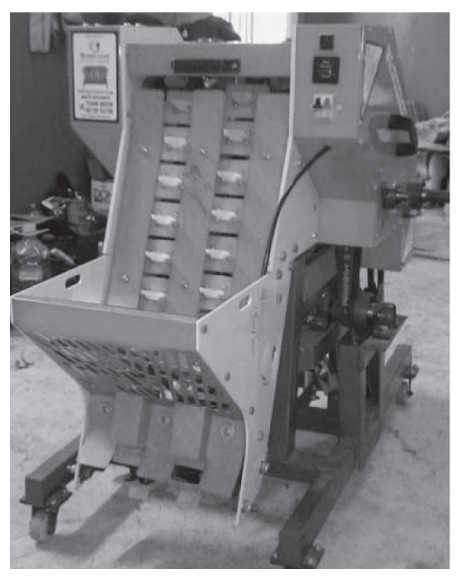

Two-belt model

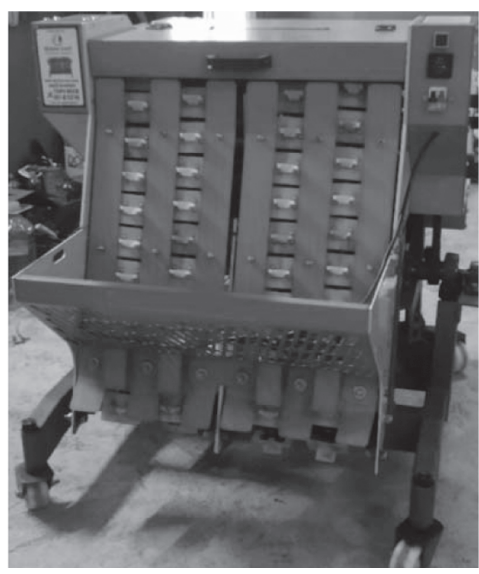

Four-belt model

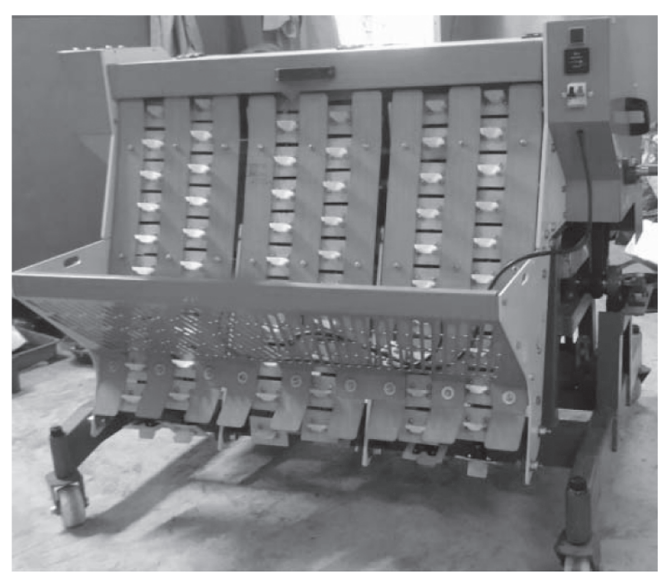

Six-belt model

Fig. 3. Various models of arecanut dehusker under evaluation 
Mechanized dehusking equipment for green arecanuts

Table 1. Specifications of three models of dehusker

Type: Power-operated

Type of conveyor: Bucket type elevator

Type of vibrator: Mechanical vibrating type with trays

\begin{tabular}{lccc}
\hline Parameters & \multicolumn{2}{c}{ Particulars } & Six-belt model \\
\cline { 2 - 4 } & Two-belt model & Four-belt model & 2 \\
\hline Power requirement (HP) & 1 & 1.5 & $1120 \times 1240 \times 1115$ \\
Overall dimension (Lx B x H), mm & $720 \times 1240 \times 1115$ & 48 & $720 \times 1240 \times 1115$ \\
Number of blades & 24 & 4 & 6 \\
Number of feeding conveyor & 2 & 330 & 390 \\
Weight of the equipment (kg) & 210 & & 72 \\
\hline
\end{tabular}

\section{Equipment for dehusking of green (tender) arecanut}

Three models of arecanut dehusking equipment viz., two-belt model, four-belt model and six-belt model were selected for evaluation (Fig. 3). The general specification of the equipment is given in Table 1.

\section{The details of important functional parts are briefed below:}

\section{Conveyor}

The conveyor is made of plastic cups attached to the conveyor chain, which forms like a bucket elevator. Conveyor cups are designed to carry single arecanut which is transferred to the dehusking zone. The number of conveyors in the dehusking machine varied from 2, 4 and 6 based on the model selected. Each conveyor has 24 cups fitted on it.

\section{Cutting wheel}

The cutting wheel is made of aluminium with a diameter of $295 \mathrm{~mm}$ and a width of $63 \mathrm{~mm}$. The wheel is provided with single or plurality of the blades. If the first wheel is provided with one blade, the next wheel is provided with more than one blade. Further, the wheel is provided with a plurality of steps or pit like openings where the blades can be fixed. Cutting wheels are fixed on a mild steel shaft of $35 \mathrm{~mm}$ diameter and 460, 810, $1165 \mathrm{~mm}$ length for three models under consideration which receives power from the gear transmission mechanism.

\section{Cutting blade}

The cutting blade is hook tooth type, made up of stainless steel. The curved blade has 12 sharp teeth on its circumference on one side with a radius of curvature $135 \mathrm{~mm}$ and a length of $145 \mathrm{~mm}$. The thickness of the blade material is $1.25 \mathrm{~mm}$. A set of cutting blade consists of 6 blades, fixed on the outer periphery of the cutting wheel. Blade imparts cutting force on the arecanut radially, which aids in dehusking operation. The depth of cutting blade (4-6 $\mathrm{mm}$ ) can be adjusted as per physical properties and condition of the nuts to be dehusked.

\section{Tub}

The tub is like a rectangular channel to allow arecanut to peel off and deliver to the vibrator trays. It is made of aluminium $(155 \mathrm{~mm} \times 85 \mathrm{~mm}$ x 80 $\mathrm{mm}$ ) and holds the arecanut against the knurl shaft for peeling. Once the husk is peeled off, the tub opens with the help of cam attached to it, to eject the dehusked nuts.

\section{Husk separator}

Husk separator is made by fixing toothed wheel to the shaft of $30 \mathrm{~mm}$ diameter with a length of $625,990,1342 \mathrm{~mm}$ for different models under investigation. Tooth removes the peeled husk which gets stuck between the blades. Teeth wheel is made up of mild steel and fixed behind the cutting wheel.

\section{Nylon brush}

Nylon brushes are attached to a mild steel shaft of diameter $20 \mathrm{~mm}$ and a length of 340,690, 1050 $\mathrm{mm}$ for different models under investigation. 
Brushes while rotating at an optimum speed, remove the fibres stuck to the wheel and blades.

\section{Knurl shaft}

Knurl shaft is made up of stainless steel of diameter $20 \mathrm{~mm}$ diameter and a length of 620,980 , $1330 \mathrm{~mm}$ for different models under investigation. The knurl shaft rotates arecanut, which was pressed by the tub to peel the husk. The knurl shaft is roughsurfaced one which gives enough friction to rotate the arecanut to a particular position enabling dehusking.

\section{Vibrator}

Vibrator consists of a deck of trays of length $910,1240,1595 \mathrm{~mm}$ for different models under investigation with a width of $250 \mathrm{~mm}$ and a total height of $220 \mathrm{~mm}$. The arecanuts after dehusking reaches the vibrator which grades the arecanuts into various categories viz., whole nuts, unhusked and partially dehusked nuts and broken nuts.

\section{Operation of equipment}

Initially, raw materials are fed into the dehusking machine through feed hopper. The nuts in the feed hopper are lifted by the plastic cups embedded on the conveyor and transferred to the dehusking zone. The teeth of the blade hold the nuts and peels off the husk while the knurling shaft rotates the nut to the required position. The tub moves forward laterally to release or allow the peeled or dehusked nut to fall into the outlet or discharge chamber, i.e., peeled or dehusked nut comes out of the machine. Husk will be removed from the blade by husk separator and discharged through the outlet.

Further, the nylon brush removes the fibres entangled in the brush. Due to the application of high shearing force, the husk is peeled off from the periphery of the nut and gets ejected to the vibrating trays. The motion of the blade and the knurling shaft is synchronised in such a way that when the blade is rotated/pushed forward in the anti-clockwise direction, the knurling shaft is rotated in the clockwise direction. Each dehusking unit is provided with two sets of cutting blades fixed in the cutting wheel deriving power for its operation from the electric motor. The motor capacity ranges from $(0.75$ to $1.5 \mathrm{~kW})$ depending on the capacity of the equipment.The sound generated by the equipment during the evaluation was recorded by the sound level meter (Make-Lutron Electronic Enterprises Co., LTD; Model-SL-4012; least count of $0.1 \mathrm{~dB}$ ).

\section{Performance evaluation of the equipment}

After the dehusking operation, 1000 numbers of arecanut was randomly sampled for a specific time of operation. Various fractions viz., whole nuts, unhusked nuts, broken nuts, partially dehusked nuts were collected from each outlet and separated manually and weighed using a balance (Make: Avery; least count of $0.01 \mathrm{~g}$ ). Each experiment was replicated five times.

Operational capacity: (Balasubramanian and Kokila, 2014)

$$
\mathrm{c}=\frac{\mathrm{q}_{\mathrm{t}}}{\mathrm{t}}
$$

where,

$\mathrm{c}$ is the operational capacity of the dehusking machine $\left(\mathrm{kg} \mathrm{h}^{-1}\right), \mathrm{q}_{\mathrm{t}}$ is the total quantity of fresh arecanuts used for dehusking $(\mathrm{kg})$ and $\mathrm{t}$ is the time taken for dehusking the given quantity (h).

Whole nut recovery efficiency (Balasubramanian and Kokila, 2014)

$$
\eta_{d}=\frac{\left(1-q_{u h}\right)}{q_{t}} \times 100
$$

where $(\%)$

$\eta_{d}$ is the whole nut recovery of the machine

$\mathrm{q}_{\mathrm{t}}$ is the total quantity of fresh arecanuts used for dehusking ( $\mathrm{kg}$ ) and $\mathrm{q}_{\mathrm{uh}}$ is the total quantity of unhusked, partially dehusked arecanuts and broken nuts $(\mathrm{kg})$.

Power consumption (Indian Standard, IS 12411:1988)

The difference between the two consecutive energy meter readings was taken as power consumption for a specific period. The power consumption $(\mathrm{kWh})$ was calculated, giving the due allowance to the type of drive. 


\section{Cost economics}

Cost economics of operation of arecanut dehusker, including fixed and variable cost was calculated as per the procedure enumerated by Regional Network for Agricultural Machinery (RNAM) test code (Anonymous, 1983). The cost of operation per hour was also worked out. The performance of various capacities of arecanut dehusker was compared with conventional manual dehusking in terms of saving in time, labour and cost. The break-even point and payback period of the equipment were also worked out as detailed below (Muthamil Selvan et al., 2007)

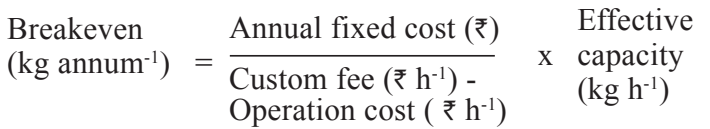

$$
\begin{aligned}
& \text { Custom fee }\left(₹ \mathrm{~h}^{-1}\right)=\left(\text { Cost of operation }\left[₹ \mathrm{~h}^{-1}\right]\right) \\
& +25 \% \text { overhead charges) } \\
& +25 \% \text { profit over new cost } \\
& \text { Payback period, years }=\frac{\text { Initial cost of equipment }(₹)}{\text { Average net annual benefit }(₹)} \\
& \text { Annual utility }=\text { Effective capacity } \mathrm{x} \text { Annual utility } \\
& (\mathrm{kg}) \quad=\quad\left(\mathrm{kg} \mathrm{h}^{-1}\right) \quad \mathrm{x} \quad \text { period }(\mathrm{h})
\end{aligned}
$$

\section{Statistical analysis}

The data were analysed as per Completely Randomised Design (CRD). Statistical significance was determined at $p<0.05$ by ANOVA, and the means were separated using Duncan's Multiple Range Test according to Panse and Sukhatme (1989). Each treatment was replicated five times.

\section{Results and discussion}

\section{Optimisation of speed of operation of equipment}

Optimisation of speed of operation of equipment dehusking of arecanut was carried out based on the speed ratio between blade shaft and knurl shaft. The performance evaluation data is given in Table 2. With the increase in the blade to knurl ratio from 1.10 to 1.11 the whole nuts recovery percentage increased significantly from $79.63 \pm 1.67$ to $85.74 \pm 1.54$ and with further increase in the blade to knurl ratio to $1: 12$, the whole nut recovery percentage reduced significantly from $85.74 \pm 1.54$ to $78.33 \pm 1.87$. The unhusked percentage reduced significantly from $10.61 \pm 1.08$ to $6.84 \pm 0.91$, with an increase of ratio from 1.10 to 1.11 . With further increase in the blade to knurl ratio to $1: 12$, the unhusked kernel percentage increased significantly from $6.84 \pm 0.91$ to $8.73 \pm 0.77$. A similar trend as that of the unhusked kernel was observed in the case of partially husked kernels.

The broken kernel percentage reduced significantly from $2.02 \pm 0.21$ to $1.05 \pm 0.12$ with the increase in the blade to knurl ratio from 1:10 to $1: 11$. With further increase in the blade to knurl ratio to $1: 12$, the broken kernel percentage increased significantly from $1.05 \pm 0.12$ to $4.27 \pm 0.38$. Based on the results of whole nut recovery, unhusked percentage, partially husked percentage and broken percentage, with the variation of the blade to knurl ratio from $1: 10$ to $1: 12$, it was observed that the highest whole nut recovery of $85.74 \pm 1.54$ per cent with lowest unhusked percentage $(6.84 \pm 0.91)$, partially husked percentage $(6.37 \pm 0.29)$ and percentage of broken nuts $(1.05 \pm 0.12)$ was

Table 2. Optimised blade-knurl shaft speed ratio analyses

\begin{tabular}{lcccc}
\hline Blade: Knurl ratio & \multicolumn{3}{c}{ \% by weight } \\
\cline { 2 - 5 } & Whole nuts & Unhusked & Partially husked & Broken nuts \\
\hline $01: 10$ & $79.63 \pm 1.67^{\mathrm{a}}$ & $10.61 \pm 1.08^{\mathrm{c}}$ & $7.74 \pm 0.38^{\mathrm{b}}$ & $2.02 \pm 0.21^{\mathrm{c}}$ \\
$01: 10.5$ & $80.72 \pm 1.77^{\mathrm{b}}$ & $10.28 \pm 1.02^{\mathrm{c}}$ & $7.35 \pm 0.36^{\mathrm{b}}$ & $1.65 \pm 0.18^{\mathrm{b}}$ \\
$01: 11$ & $85.74 \pm 1.54^{\mathrm{c}}$ & $6.84 \pm 0.91^{\mathrm{a}}$ & $6.37 \pm 0.29^{\mathrm{a}}$ & $1.05 \pm 0.12^{\mathrm{a}}$ \\
$01: 11.5$ & $82.75 \pm 1.49^{\mathrm{b}}$ & $7.17 \pm 0.89^{\mathrm{a}}$ & $6.62 \pm 0.3^{\mathrm{a}}$ & $3.46 \pm 0.29^{\mathrm{d}}$ \\
$01: 12$ & $78.33 \pm 1.87^{\mathrm{a}}$ & $8.73 \pm 0.77^{\mathrm{b}}$ & $8.67 \pm 0.69^{\mathrm{c}}$ & $4.27 \pm 0.38^{\mathrm{e}}$ \\
\hline $\mathrm{CD}(0.05)$ & 2.97 & 1.33 & 0.57 & 0.23 \\
\hline
\end{tabular}

Values followed by same letters are not significantly different 


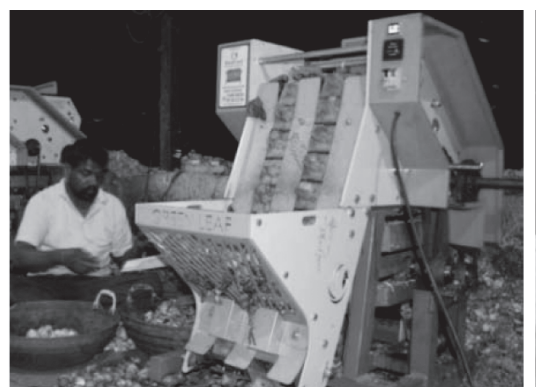

Two-belt model

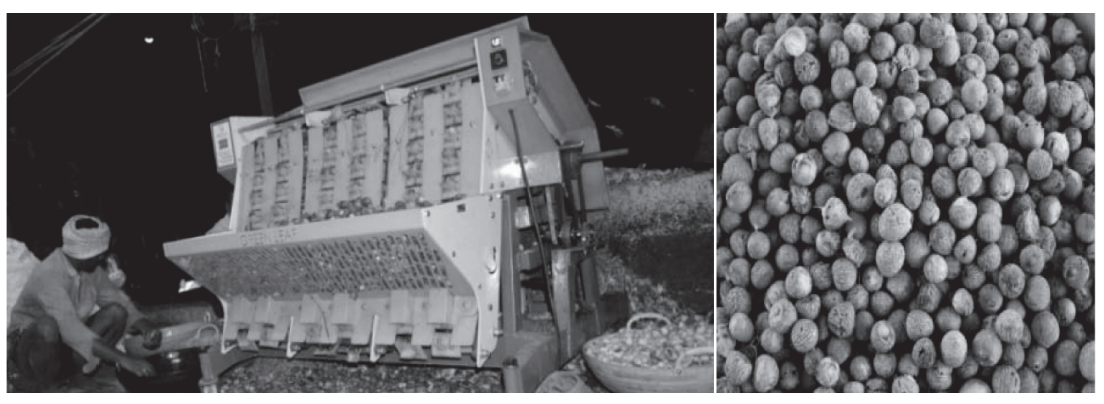

Six-belt model

Dehusked arecanut

Fig. 4. Performance evaluation of the arecanut dehuskers

observed at the blade to knurl ratio of 1:11. Keeping these results as a base, all the models of the arecanut dehusking under evaluation was operated by using the fixed blade to knurl ratio of 1:11 (Vishwanathan, 2014; Patent No. 259204).

\section{Comparative performance of the mechanised dehusking machine}

Various models of dehusking machine for fresh arecanuts under investigation was evaluated for its performance in terms of operational capacity, dehusking efficiency compared with the traditional manual dehusking method (Fig. 4). The performance evaluation of the three models of dehusker is given in Table 3.

\section{Operational capacity}

The operational capacity of mechanical dehusking was found to be $379.7 \pm 9.46,683.0 \pm 6.48$ and $984.7 \pm 4.64 \mathrm{~kg} \mathrm{~h}^{-1}$ for two-belt, four-belt and six-belt model of arecanut dehuskers, respectively. The capacity of manual dehusking was 5 to $6 \mathrm{~kg} \mathrm{~h}^{-1}$. Variation in the dehusking capacity in the three models under investigation was mainly due to the number of belts. In the case of manual dehusking, the operator needs to apply the force required to peel the husk using a knife. The application of force by the machine is limited in such a way that blades penetrate to required depth without damaging nut inside the shell. When dehusking was done by hand, the operators experienced drudgery as the time elapsed. Therefore the average capacity per labour was 5-6 $\mathrm{kg} \mathrm{h}^{-1}$ which was lower than mechanical dehusking. In mechanised dehusking operation, nuts were lifted one by one and transferred to the dehusking zone. Operational capacity varied with the number of belts in accordance with the size

Table 3. Performance of three models of arecanut dehusker

\begin{tabular}{|c|c|c|c|c|c|}
\hline $\begin{array}{l}\text { Sl. } \\
\text { No. }\end{array}$ & Parameters & & Two-belt model & Four-belt model & Six-belt model \\
\hline 1. & Operational capacity $\left(\mathrm{kg} \mathrm{h}^{-1}\right)$ & & $379.7 \pm 9.46$ & $683.0 \pm 6.48$ & $984.7 \pm 4.64$ \\
\hline 2. & Whole nuts (\%) & & $81.84 \pm 1.87$ & $82.12 \pm 2.48$ & $82.52 \pm 1.95$ \\
\hline 3. & Unhusked nuts (\%) & & $7.81 \pm 4.68$ & $7.78 \pm 4.47$ & $7.60 \pm 3.71$ \\
\hline 4. & Partially husked (\%) & & $8.29 \pm 2.15$ & $8.72 \pm 2.10$ & $8.85 \pm 2.82$ \\
\hline 5. & Broken nuts $(\%)$ & & $2.06 \pm 2.72$ & $1.38 \pm 1.98$ & $1.03 \pm 1.36$ \\
\hline 6. & Cutting wheel shaft speed (rpm) & & $80.00 \pm 0.47$ & $83.00 \pm 0.82$ & $84.00 \pm 0.82$ \\
\hline 7. & Knurling shaft speed (rpm) & & $881 \pm 15.28$ & $910 \pm 8.29$ & $925 \pm 3.09$ \\
\hline 8. & Power consumption $\left(\mathrm{kW} \mathrm{h}^{-1}\right)$ & & $0.77 \pm 0.02$ & $1.21 \pm 0.02$ & $1.26 \pm 0.03$ \\
\hline \multirow[t]{2}{*}{9.} & Sound/noise during operation $(\mathrm{dB})$ & Maximum & $89.44 \pm 0.29$ & $89.67 \pm 0.13$ & $86.19 \pm 0.31$ \\
\hline & & Minimum & $85.91 \pm 0.62$ & $87.91 \pm 0.15$ & $83.51 \pm 0.30$ \\
\hline
\end{tabular}


and positioning of the nut during the dehusking process.

\section{Performance evaluation of equipment}

Performance of equipment was evaluated in terms of whole nut recovery per cent, unhusked nut per cent, partially husked nut and broken nut per cent. The whole nut recovery per cent ranged from $81.84 \pm 1.87$ to $82.52 \pm 1.95$. The unhusked per cent and partially husked percentage ranged from $7.60 \pm 3.71$ to $7.81 \pm 4.68$ and $8.29 \pm 2.15$ to $8.85 \pm 2.82$, respectively. The broken nut percentage ranged from $1.03 \pm 1.36$ to $2.06 \pm 2.72$. The power consumption of two belt model, four belt model and six belt model of dehusker were $0.77 \pm 0.02$, $1.21 \pm 0.02$ and $1.26 \pm 0.03 \mathrm{kWh}$, respectively.

\section{Noise level}

For agricultural machines, the noise level is an important ergonomically aspect as it has effects on the hearing ability of the workers. As per the Occupational Safety and Health Administration (OSHA; www.osha.gov/laws-regs/regulations/ standard number/1910/1910.95), the permissible exposure limit (PEL) is $90 \mathrm{~dB}$ for all workers for an 8-hour day. In the three models under evaluation, the maximum sound level was in the range of $86.19 \pm 0.31$ to $89.44 \pm 0.29 \mathrm{~dB}$, and the minimum sound level was in the range of $83.51 \pm 0.30$ to $85.91 \pm 0.62 \mathrm{~dB}$, which was well within the permissible accepted limit and hence acceptable.

\section{Economics of various models of arecanut dehusker}

The data and information collected both on the conventional method of dehusking and by using mechanised dehusking machine were analysed for the cost of dehusking. For working out the cost economics of the equipment, the

Table 4. Fixed and operational cost calculation of different models of arecanut dehusker

\begin{tabular}{|c|c|c|c|c|c|c|}
\hline \multirow[t]{2}{*}{ Parameters } & \multicolumn{2}{|c|}{ Two-belt model } & \multicolumn{2}{|c|}{ Four-belt model } & \multicolumn{2}{|c|}{ Six-belt model } \\
\hline & $\begin{array}{c}\text { Cost } \\
\text { annum }^{-1}\end{array}$ & $\begin{array}{c}\text { Cost } \\
h^{-1}\end{array}$ & $\begin{array}{c}\text { Cost } \\
\text { annum }^{-1}\end{array}$ & $\begin{array}{c}\text { Cost } \\
h^{-1}\end{array}$ & $\begin{array}{c}\text { Cost } \\
\text { annum }^{-1}\end{array}$ & $\begin{array}{c}\text { Cost } \\
h^{-1}\end{array}$ \\
\hline Salvage value@10\% of initial cost (₹) & 13000 & 11 & 19500 & 16 & 26000 & 22 \\
\hline Depreciation (₹) & 16714 & 14 & 25071 & 21 & 33429 & 28 \\
\hline Interest @ 15\%(₹) & 10725 & 9 & 16088 & 13 & 21450 & 18 \\
\hline Taxes $1 \%$ of purchase price $(₹)$ & 1300 & 1 & 1950 & 2 & 2600 & 2 \\
\hline Insurance $1 \%$ of average price (₹) & 1300 & 1 & 1950 & 2 & 2600 & 2 \\
\hline Repair \& maintenance $8 \%$ of initial cost (₹) & 10400 & 9 & 15600 & 13 & 20800 & 17 \\
\hline Fixed cost (₹) & 53439 & 45 & 80159 & 67 & 106879 & 89 \\
\hline Power of the prime mover (hp) & 1 & & 1.5 & & 2 & \\
\hline Power used: (total no of hyr $^{-1}$ ) & 1200 & & 1200 & & 1200 & \\
\hline Power required to operate the prime mover $\left(\mathrm{kW} \mathrm{h}^{-1}\right)$ & 0.75 & & 1.12 & & 1.5 & \\
\hline Power used (units year-1) & 900 & & 1344 & & 1800 & \\
\hline Cost of power consumption @ ₹ 6.00 unit $^{-1}$ (₹) & 5400 & & 8064 & & 10800 & \\
\hline Labourers required (no.) & 2 & & 3 & & 3 & \\
\hline Labour wages (₹ person ${ }^{-1}$ ) & 400 & & 400 & & 400 & \\
\hline Total working days & 150 & & 150 & & 150 & \\
\hline Labour wages per year (₹) & 120000 & & 180000 & & 180000 & \\
\hline Housing (₹ month ${ }^{-1}$ ) & 1000 & & 1000 & & 1000 & \\
\hline Housing ( $₹$ year ${ }^{-1}$ ) & 12000 & & 12000 & & 12000 & \\
\hline Operating cost (₹) & 141054 & 118 & 204164 & 170 & 207357 & 173 \\
\hline Total cost (₹) & 194493 & 162 & 284323 & 237 & 314235 & 262 \\
\hline
\end{tabular}


Table 5. Break-even point and payback period of different models of arecanut dehusker

\begin{tabular}{lccr}
\hline Parameters & Two-belt model & Four-belt model & Six-belt model \\
\hline Custom fee $\left(₹ \mathrm{~h}^{-1}\right)$ & 184.00 & 266.00 & 270.00 \\
Effective capacity $\left(\mathrm{kg} \mathrm{h}^{-1}\right)$ & 340.00 & 616.00 & 850.00 \\
Break-even point $(\mathrm{kg})$ & 274798.00 & 516166.00 & 934654.00 \\
Average net annual benefit (₹) & 79343.00 & 114842.00 & 116638.00 \\
Payback period (years) & 1.64 & 1.70 & 2.23 \\
\hline Per cent savings in time, labour and cost of different models of arecanut dehusker & 93.80 & 95.70 \\
\hline Saving in time (\%) & 88.80 & 81.25 & 86.96 \\
Saving in labour $(\%)$ & 77.78 & 70.60 & 77.40 \\
Saving in cost $(\%)$ & 63.60 & & \\
\hline
\end{tabular}

cost of dehusker was assumed to be ₹ 1.30 lakh, 1.95 lakh and 2.60 lakh for two-belt, four-belt and six-belt models, respectively with the annual usage of $1200 \mathrm{~h}$. The life of dehusker was assumed seven years with the salvage value of 10 per cent. Straight-line method was used for economic cost calculation (Table 4).

From Table 4, it is seen that the total cost of operation for two-belt, four-belt and six-belt model was ₹ $162 \mathrm{~h}^{-1}$, ₹ $237 \mathrm{~h}^{-1}$ and ₹ $262 \mathrm{~h}^{-1}$, respectively. The custom fee of the equipment is ₹ $184 \mathrm{~h}^{-1}$, ₹ $266 \mathrm{~h}^{-1}$ and ₹ $270 \mathrm{~h}^{-1}$. Effective capacity of 340 , 615 and $850 \mathrm{~kg} \mathrm{~h}^{-1}$ was recorded for the three models of dehuskers under investigation. The corresponding break-even period of three models was $1.64,1.70$ and 2.23 years, respectively (Table 5).

\section{a) Cost of dehusking by manual method}

The capacity of the two-belt model, four-belt model and six-belt model of arecanut dehuskers were $375 \mathrm{~kg} \mathrm{~h}^{-1}, 675 \mathrm{~kg} \mathrm{~h}^{-1}$ and $975 \mathrm{~kg} \mathrm{~h}^{-1}$, respectively

i. Quantity of arecanut dehusked by one woman labour per day $=40-45 \mathrm{~kg}$, say $42 \mathrm{~kg}$

ii. Wages per women per day $=₹ 400$

iii. Number of women days to dehusk $375 \mathrm{~kg}=8.9$ women days

iv. Number of women days to dehusk $675 \mathrm{~kg}=16.1$ women days

v. Number of women days to dehusk $975 \mathrm{~kg}=23.2$ women days

vi. Cost to dehusk $375 \mathrm{~kg}=₹ 3560$

vii. Cost to dehusk $675 \mathrm{~kg}=₹ 6440$

viii. Cost to dehusk $975 \mathrm{~kg}=₹ 9280$
The cost economics study revealed significant percentage saving in time, labour and cost by the adoption of the arecanut dehusker for dehusking of green arecanut (Table 5). Per cent saving in time, labour and cost ranged from 88.80 to 95.70 per cent, 77.78 to 86.96 per cent and 63.60 to 77.40 per cent for two-belt model, four-belt model and six-belt model, respectively. As the capacity increases, the per cent saving in time, labour and cost also increased due to the higher capacity of the equipment per unit time. Thus, it was seen that the high capacity arecanut dehusker for green arecanuts could be adopted in the arecanut production catchment, thereby leading to entrepreneurship development. This would lead to strengthening of quality raw material in the supply chain of industries involved in the production of the value-added products from arecanut, as the dehusking process could be carried out within the recommended time after harvesting.

\section{Conclusion}

Dehusking of green arecanut is a time consuming, but very important unit operation in the processing of green arecanut. This operation needs to be completed within 24-36 hours after harvesting so that the best quality product reaches the post-harvest value chain. Hence, there is a need to adopt high capacity green arecanut dehusking machine. Performance evaluation of three models of the dehusker revealed significant percentage saving in time, labour and cost by the adoption of the arecanut dehusker for dehusking of green arecanut. The effective capacity of the three models 
is 340,615 and $850 \mathrm{~kg} \mathrm{~h}^{-1}$ with corresponding breakeven period of $1.64,1.70$ and 2.23 years, respectively. The equipment can be adopted by entrepreneurs at the arecanut catchment, thus generating revenue and getting a better finished product as dehusking can be carried out within the stipulated time.

\section{Acknowledgement}

The authors are thankful to M/s Green Leaf, Machenahalli, Shivamogga, Karnataka, India for assisting in carrying out long term trials of the machine for dehusking fresh green arecanuts.

\section{References}

Alfaz, Abhishek Gowda, G.A., Anand, B.S., Anvesh, K. and Harish, K. 2018. Fabrication of arecanut dehusking machine. International Journal of Information and Computing Sciences 5(5): 0972-1347.

Anand, S.R., Murthy, C., Mahajanashetti, S.B. and Venugopal, C.K. 2012. Value addition and marketing efficiency in arecanut processing units. Karnataka Journal of Agricultural Sciences 25(1): 77-81.

Anonymous 1983. RNAM Regional Network for Agricultural Machinery. Test Codes and Procedures for Farm Machinery. Technical Series No.12. Bangkok, Thailand, pp. 219.

Asokan, D., Manohar Jesudas, D., Kavitha, R. and Senthilkumar, T. 2014. Design and development of dehusker suitable for fresh arecanut. Journal of Plantation Crops 42(1): 101-107.

Aviara, N.A., Onuh, O.A. and Ehiabhi, S.E. 2012. Influence of moisture content and loading orientation on some mechanical properties of Mucuna flagellipes nut. Research in Agricultural Engineering 58(2): 66-72.

Aware, V.V., Seema, V., Shahare, P.U., Shirsat, N.A., Patil, M.R. and Kavitkar, C.R. 2016. Ergonomic evaluation of pedal operated arecanut dehusker with women workers in the Konkan region of Maharashtra. Agriculture Update HAS 11(3): 273-276.

Baboo, B. 1981. A device for dehusking arecanut. Journal of Agricultural Engineering 19(1): 63-65.

Balasubramanian, D. and Kokila, J.R.L. 2014. Performance evaluation of mechanised shelling machine for steam treated raw cashewnuts. Journal of Plantation Crops 42(2): 185-190.

Balasubramanian, M. and Panwar, J.S. 1986. Mechanical properties of arecanut (Areca catechu Linn.) as related to dehusking. Journal of Agricultural Engineering 23(1): $82-88$.
Bellubbi S, Umesha, Shivaling, Y., Shantkumar and Manjunatha, D.V. 2018. Pedal operated arecanut peeling and crops dehusking mechanism. Karnataka International Research Journal of Advanced Engineering and Sciences 3(2): 222-223.

Indian Standard: IS 12411-1988. Specification for paddy dehusker, Centrifugal type.

Jarimopas, B. and Niamhom, S. 2004. Development of Dry Betel Nut Fruit Shelling Machine. Unpublished Research Report. Kasetsart University Research and Development Institute, Kasetsart University, Bangkok, $46 \mathrm{p}$.

Jarimopas, B., Niamhom, S. and Terdwongworakul, A. 2009. Development and testing of a husking machine for dry betel nut (Areca catechu Linn.). Biosystems Engineering 102:83-89.

Joy, N.M., Mathew, M.,Jijin, K. and Anoop, V.M. 2015. Design, development and testing of green betel nut husking machine. International Journal of Engineering Innovations and Research 4(5): 686-690.

Kiran, K., Govin, A.K., Bandi M. and Shivasharanyya. 2014. Design, development and testing of an arecanut dehusking agri-machine. Karnataka Journal of Engineering Research and Applications 4(7): 109-115.

Muthamil Selvan, M.,Rangasamy, K. and Sampathrajan, A. 2007. Feasibility and economic viability of knapsack cotton picker in India. Indian Journal of Agricultural Sciences 41(2): 86-91.

Nalawade, S.M., Gajakos A.V. and Kad, V.P. 2018. Development of manually operated areca nut dehusker. Quarterly Journal in Science, Agriculture Engineering 7(25): 346-348.

Niamhom, S., Jarimopas, B. and Sukcharoen, A. 2007. Testing of the improved betel nut shelling machine. In: Proceeding of the International Conference on Agricultural, Food and Biological Engineering and Post Harvest /Production Technology, January 21-24, 2007, Sofitel Racha Orchid Hotel, Khon Kaen, Thailand, pp. 21-34.

Panse, V.E. and Sukhatme, P.V. 1989. Statistical Method for Agricultural Workers. ICAR, New Delhi, 361p.

Pradeep, C. and Raghavendra, B.V. 2012. Study and analysis of arecanut peeling process using design of experiment. Karnataka International journal of Engineering Innovations and Sciences 1(5): 399-406.

Ramappa, B.T. and Manjunatha, M.S. 2013. Cost of cultivation of arecanut at non-traditional region of Karnataka-An Analysis. International Journal of Pharmaceutical Science Invention 2(3): 25-31.

Suhas, M.P., Vinodkumar, R., Tavankeerti, A., Vinayak, B. and Arun Kumar, M.R. 2016. Design, development and 
testing of an arecanut dehusking agri-machine using optical reorganisation. International Journal of Engineering Research in Computer Science and Engineering 3(11): 81-85.

Varghese, F. and Jacob, J. 1998. Design, fabrication and testing of arecanut dehusker. Agricultural Mechanization in Asia, Africa, and Latin America 29(1): 27-30.

Vijayakumar, G., Kavya Bai, B.G., Mahesh, Rohith, M. and Shashikumar, S.H. 2017. Design and fabrication of dehusking machine of arecanut. Karnataka International Journal of Innovative Research in Science, Engineering and Technology 6(15): 102-106.
Vion, J.M., Venkatesh, M.N., Gauthami, P.S., Deepak, D.N, Yathish, K., Binu, K.G., Shetty, A. and Joel D' Mello. 2017. Design and fabrication of arecanut processing unit. Journal of Mechanical Engineering and Automation 7(5): 155-158.

Vishwanathan, K. 2014. A machine for dehusking the skin of arecanut. Patent number 259204; 1891CHE/2007, PG Journal 10/2014.

www.dasd.gov.in. Accessed on 01.06.2020. Website of Directorate of arecanut and Spices Development, Calicut, Kerala, India.

www.osha.gov/laws-regs/regulations/standardnumber/1910/ 1910.95 Accessed on 01.06.2020. Occupational Safety and Health Administration. 